\title{
Dialogue
}

\section{Oceanic Historicities}

CHRIS BALLARD

Being "Nesian": Pacific Islander Identity in Australia KIRSTEN MCGAVIN

The Contemporary Pacific, Volume 26, Number I, Spring 20I4, 95-I 54 (C) 2014 by University of Hawai'i Press 


\section{Being "Nesian": \\ Pacific Islander Identity in Australia}

Kirsten McGavin

Oh Pasifik Ailans yumi wan bik famili

No matter difren kantris we are wan

(Oh Pacific Islands we are one big family

No matter different countries we are one)

- Patti Potts Doi,

Papua New Guinean singer ${ }^{1}$

In 2009, two of my friends (she from Papua New Guinea and he from New Zealand) married at Queensland's Gold Coast. Their celebration had all the hallmarks of a typical wedding and Islander event: music, singing, dancing, lots of people, and even more food. Amidst it all were dancers in "traditional" Island dress, performing hula to celebrate the union in "Island style." Despite there being no traditional hula from Papua New Guinea or from New Zealand, diasporic Islander communities often perform the "traditional" Hawaiian dance on social gatherings. ${ }^{2}$ In a subsequent conversation, Darlene ${ }^{3}$ - a woman in her thirties who identifies as an Australian South Sea Islander ${ }^{4}$ (and who was not at the wedding)-told me that members of her community also perform hula at birthday parties and special events. Indeed, in borrowing aspects of other Island cultures, diasporic Islanders might be said to affirm their own distinct culture, assert the commonalities of Islander cultures in general, and support Islanders' connections to each other. I later spoke with Sara, a Samoan woman in her late teens (not present at the wedding), who explained that in her opinion, such cases of emergent "authenticity" (as I label them) are an expected part of being "Nesian." This term, predicated on the panethnic qualities of the label "Islander," ${ }^{5}$ is emerging in online forums and social network-

The Contemporary Pacific, Volume 26, Number I, I26-I 54

(C) 2014 by University of Hawai' $i$ Press

I 26 
ing sites to denote a person of Islander descent. Being Nesian is just one label that reflects the important concept of Pacific Islander panethnicity as promoted by community organizations and elders.

Tracy McFarlane described "panethnicity" as being an analytical term applicable to an identity label that "transcend[s] national boundaries and [allows the formation of communities] based on cultural background and similarity of experiences prior to and since" becoming part of a diaspora (20IO, IOI). ${ }^{6}$ For example, McFarlane's 20I0 work explores the panethnic Caribbean (and the possibility of pan-African) identities of individuals from the Dominican Republic, Haiti, Jamaica, and Trinidad who currently live in the United States. Similarly, Milagros Ricort and Ruby Danta examined Latino/a panethnicity and its corresponding community constituted by people of Cuban, Puerto Rican, and Colombian descent in New York (2003). Importantly, the panethnic category subsumes but does not negate ethno-national identity labels. As Noel Pearson explained in the context of Australian Aboriginal settings (2006), every person's identity is "layered," context dependent, and without any absolute boundaries. For Pacific Islanders in Australia, panethnicity becomes an important factor of identity for Fijians, Papua New Guineans, Samoans, Tuvaluans, and Tongans (and for Islanders from other countries) living in diasporic settings across the state of Queensland.

Fredrik Barth argued that ethnic groups (and, I argue, panethnic groups also) are defined not only by their "internal" cultural content, but also by their boundaries, however flexible these may be (Barth I998, 6). Ethnic boundaries are not a result of group isolation; they persist and thrive in circumstances in which ongoing interaction between different groups takes place (Barth I998, 10). Indeed, these boundaries fluctuate and are permeable, just as the culture within the boundary is dynamic. Importantly, this point is valid for "single ethnicity" and "multiethnicity," as well as for panethnicity. To present my use of these analytical terms, consider an illustrative (hypothetical) example: Dwayne's "single" ethnicity is Samoan (ie, he identifies as "pure" Samoan, regardless of where he was born or grew up), while Nicole's multiethnic (or "multiracial") identity stems from her Hawaiian, Filipino, and Russian descent). In the setting of my research in southeast Queensland, both Dwayne and Nicole's panethnic identity is "Pacific Islander." As with Paul Spickard's study of multiethnic Pacific Islanders in the United States $(2002,46)$, the dynamism of such multilayered identities involves individuals choosing to highlight certain aspects of their ethnicity according to circumstance. 
As the author of this dialogue piece, I believe it relevant to acknowledge my ancestry: I am a Lavongai woman from the New Guinea Islands; I am also a New Zealand Pākehā woman. Furthermore, I am an Australian and a member of the Pacific diaspora. My role as an advisory group member for a number of pan-Pasifika community organizations links me with a panethnic Islander identity shared and utilized by other community group members from the Cook Islands, Fiji, Hawai'i, Kiribati, New Zealand, Sāmoa, Tonga, Tahiti, and Tuvalu. In the way of many Pacific Islanders and Pacific Islander scholars (Anae 20I0; Tengan and others 20I0; Kauanui 2007, I50; Smith 2004, 5), I acknowledge the importance of genealogy in relation both to my Islander identity and to my research. This approach is underscored by the work of Black feminist anthropologists such as A Lynn Bolles (200I, 25), Angela Gilliam (200I, I 50), Irma McClaurin (200I, 49), and Karla Slocum (200I, I26), who have argued for the relevance of position and ancestry (both personal and academic) in relation to "insider" anthropology.

Similarly, Edward Bruner and Victor Turner asserted the importance of including the experiential components of personal narrative and biography in ethnographic accounts, as these elements make explicit the notion that anthropologists tell their own stories about the stories of others (I986, 9-IO). It is important to note that I report on cultural knowledge that I have acquired through my own socialization, made possible through this insider position. One effect of this is my inclusion of research participants regardless of birthplace. This is a reflection of my adherence to the Papua New Guinean notion that a person is connected to their "peles" (place) and "homeland" no matter the distance in time or space that separates them, from birth till beyond death. ${ }^{7}$ However, I also recognize the important work conducted among other Pacific Islander diasporas that does mark this difference (between diasporic-born and homeland-born) as significant (Tagata Pasifika 2007). Also, although I realize that highlighting "mixed-race" and non-"mixed-race" experiences offers further depth to the layers of identity that I describe, that is not my focus here.

In this essay, I explore the manner and situations in which Pacific Islanders in Australia self-define as Islanders. Further, I examine the circumstances in which the panethnic qualities of Pacific Islander identity emerge. To do this, I draw on research undertaken across southeast Queensland between 2008 and 20I2, focusing on events and interactions involving people of Pacific Islander descent who were eighteen years or older and current residents of Australia (whether citizens, permanent residents, or 
long-term residents, eg, on student visas). Specifically, I use examples associated with formalized community groups, cultural events, and social functions. My access to these data continues to be facilitated by my positioning as an Australian of Pacific Islander descent and by my involvement with pan-Pasifika organizations. I also draw on ethnographic notes on conversations and observations made in Byron Bay, Sydney, Tweed Heads (all in New South Wales), and Melbourne (in Victoria) within the same time period.

The conceptual framework for my research is informed by Jocelyn Linnekin and Lin Poyer's argument that "regional and global historical processes have been and continue to be major factors in the shaping of Pacific Island identities" (I990, 4). Most significantly, this is illustrated by Epeli Hau'ofa's seminal work (I993) and also, later, Paul D'Arcy's (2006, 98), which each conceptualize the Islands and people of the Pacific as defined and connected (rather than separated) by the sea. For example, the historical dispersion of Lapita pottery from the New Guinea Islands into parts of southern Polynesia (Sheppard 201 I, 799); relationships of exchange between Yap and Palau (D'Arcy 2006, I44); the arrival of Europeans (D'Arcy 2006, I 25); and Tahitian missionaries in the Cook Islands and Samoan and Fijian missionaries in Papua New Guinea (Wetherall 2002, 79) all indicate the complex history of the region and the kinds of influences on the creation and shifting of ethnic boundaries. As Eugeen Roosens attested (I989, I2-I3), ethnic identity is shaped by social, political, or economic interests, and these change over time and according to setting. Therefore, it is apposite to acknowledge that the context for the data I present in this piece is shaped not only by sociopolitics within home Island nations (Shain 2002, I I 5-I I6), but also by Australia's historical and contemporary relationship with the Pacific region in terms of both national government politics and the beliefs and behaviors of "ordinary people" (Hau'ofa I993, 2). This recognition adds depth to an understanding of the experiences of Pacific Islanders in Australia and reflects what Hau'ofa described as dual levels of operation, whereby people positioned at different national political and institutional or local community levels experience and shape the Pacific in divergent ways (1993, 2). For example, Michael Perez described the ways in which Chamorro people identify "racially" against the backdrop of state-bound definitions and politics that otherwise attempt to marginalize and homogenize them in the United States (2002, 467-476). For these reasons, I now describe Australia's relationship with the Pacific 
in order to provide some context for the ways in which people self-define as Islanders.

\section{Australia's Relationship with the Pacific}

A former colonial administrator of Papua New Guinea, Australia has a continuing trade and aid relationship with many Pacific states. Two major ethnic groups link Australia inextricably to the Pacific region: Australian South Sea Islanders and Torres Strait Islanders, ${ }^{8}$ an Indigenous Australian population from the Melanesian islands between the northern tip of Queensland and the Gulf of Papua New Guinea. However, it is important to note that when the Pacific region underwent decolonization in the latter half of the twentieth century, countries such as the United States and New Zealand "opened pathways for migration for Islanders with whom they had colonial ties" (Lee 2009, 8), while Australia did not. Indeed, Australia's "White Australia" policy, effective from I90 I to I973, discouraged Pacific migration (Lee 2009, II) and saw the deportation of many Australian South Sea Islanders back to "home" islands where they had never lived. Not until 1994 did Australia formally acknowledge Australian South Sea Islanders as a distinct ethnic group, with Queensland offering the group official legal recognition in 2000 (MADASSIA 2000).

More recently, Australia's "Pacific Solution," in place from $200 \mathrm{I}$ to 2007 and reinstated in 2012, saw refugees and asylum seekers sent to offshore detention centers in Nauru and Papua New Guinea while their visa applications were being processed (Connell 2006, 55). Talk of reviving this scheme (between 2007 and 20I2) saw some Island nations (eg, Solomon Islands) attempt to negotiate their participation as "hosts" in future incarnations of the Pacific Solution (Sydney Morning Herald 20I I), as the Papua New Guinea and Nauru governments did receive compensation. However, individual Islanders I have encountered in the course of my research were angry, perceiving the scheme as assisting Australia while offering Pacific Islanders no benefit in return. According to Magda (a Fijian woman), "They [Australia] just take, take, take. It was so hard for me to come here. I had to jump through all these hoops. Now they make these refugee camps in the Islands and what do they give us [Pacific Islanders]? Nothing. It's still hard for Islanders to come here." To clarify, this kind of statement is unrelated to Islanders' feelings toward refugees and asylum seekers; nor is it about these groups' access or entry to Australia. Instead, this example highlights some Islanders' belief that reciproc- 
ity (a vital characteristic of the "Melanesian/Pacific Way") is an important but seemingly missing part of Australia's relationship with its Pacific Island neighbors. Hosting refugees and asylum seekers is seen as a favor the Pacific is doing for Australia and, in return, some Islanders would like Australia to make it easier for Islanders to visit or migrate here.

Indeed, Australia's increasing preference toward skills-based migration and favoring migrants with capital has "meant that Fijians (and others) have found it increasingly difficult to obtain permanent entry to Australia.... Fijians have had to deploy entry tactics to Australia such as marriage to an Australian citizen for visa sponsorship, and overstaying ... on a tourist visa, as a means of delaying or avoiding return to Fiji" (Schubert 2009, I 35). The Pacific Seasonal Workers scheme, introduced in 2008, is aimed at i-Kiribati, Papua New Guineans, ni-Vanuatu, and Tongans and allows Islanders to stay in Australia for up to six months, mainly to work in laborer positions during harvesting periods on farms. This scheme has also generated some discontent among Islanders with whom I have spoken who are living in Australia, who make loose comparisons between this and the blackbirding schemes that initially brought South Sea Islanders to this country. Eddie (a Papua New Guinean in his mid-thirties) said, "Plantation work? They [Australia] want us here for these low jobs only. They don't give us scholarships for school or uni [university] or help us to come here permanently. They treat us like nothing and we're [Papua New Guineans] their closest neighbors!"

The type of reaction expressed by Magda and Eddie in the examples above indicates maintenance of a level of identification with home Island groups rather than with new host cultures among Islanders currently living in Australia. There are, of course, a multitude of differing perspectives when considering Islanders' sense of belonging. Belinda (of New Guinea Islander descent and in her late fifties) proclaims herself to be Australian. She said, "I hate it when people ask me where I'm from. I went to school here, my kids were born here, I speak like an Australian. When will people learn? I'm Australian." Belinda's statement reveals that although she does feel an affinity to an Australian identity, her sense of belonging is challenged by others in the broader Australian community.

Despite the range of perspectives I have recorded in terms of Islanders' sense of belonging, and the negative feedback regarding some of Australia's Pacific-related policies, Islanders continue to want to come to Australia. Commonly cited "pull" factors include opportunities in employment and education not readily accessible in the Islands and integration into 
existing Islander kinship networks. The Pacific region (especially countries such as Fiji and Vanuatu) contains some of Australia's favorite tourist destinations (Harrison 2004, 9), although it is unclear how much of this travel is constituted by Islanders visiting family and friends or reconnecting with personal or ancestral heritage places in home Islands. Importantly, regardless of visas or statistical responses on entry cards, an issue germane to my research is the extent to which Islanders visit the Islands not as tourists but as a part of a "homecoming" that strengthens their ethno-cultural identity. Although this article focuses on Pacific Islanders in Australia, I recognize that the experiences of these groups in home Islands and elsewhere abroad may also play a role in how they identify (Shain 2002, II5-II6). The relevance of this point is evident in the following section, in which I discuss the links between terminology use and the complexities of the terms "Islander" and "Pacific Islander."

\section{Terminology}

Terminology used to describe Pacific Islanders-including the multivocal use of "Pacific Islander"-is contested both in academic circles and at the community level. For the purpose of my research, I use the term "Pacific Islander" to include any person of Melanesian, Micronesian, or Polynesian descent. Although this definition corresponds with popular understanding (D'Arcy 2006, I 83), it is controversial in a number of ways.

First, the validity of using the terms "Melanesia," "Micronesia," and "Polynesia" has long been under debate (Clark 2003). French scholar Charles de Brosses is credited as the first to use the term "Polynesia" in I 756, although at the time the term was used to refer to all of the Pacific Islands (Jolly 2007, 535). By the I 830 os, based on Europeans' observations of perceived differences in "race" and place in the Pacific," other French scholars followed Dumont d'Urville in distinguishing between Melanesia, Micronesia, and Polynesia (Jolly 2007, 519). Geoffrey Clark argued that if the terms had been used only to describe geographical differences in the three Island regions there would be little controversy (2003, I 57). However, other scholars have criticized the terms for their non-Pacific origin and their early use in ranking differences in "race" and cultural practice in a socio-evolutionary hierarchy (Clark 2003, I 57-I 58 ; Hau'ofa I993, 3; Smith 2004, 4-9).

Second, some academics exclude Melanesians-and especially Papua New Guineans-from the category of "Pacific Islander.” D'Arcy did this 
as a result of choosing to focus on the "truly oceanic domain" of Remote Oceania, a zone closely corresponding with Polynesia and parts of Micronesia and characterized by "large sea gaps between islands and archipelagos" (2006, I). This distinction between "Near" and "Remote" Oceania is also reinforced in some biological and archaeological texts (Kayser 2009, I94; Sheppard 2011, 799).

Third, particular groups of people are often excluded from consideration as "Pacific Islander" for political or social reasons. For example, Māori people are often overlooked in terms of this category. Many Pacific Islanders enter Australia as citizens of New Zealand, with some having lived there for many years if not since birth (Lee 2009, I I). In New Zealand, many people differentiate between Māori and other Polynesians by referring to only the latter group as Pacific Islanders. This is despite some Māori people self-defining as Islanders. On one occasion in which I was present, in a conversation about similarities between Māori and Papua New Guinean culture, Ben (a Māori man in his twenties) said to Eddie (a Papua New Guinean man in his thirties), "We're all Islanders anyway." 10

Despite the disparity of these critiques, I have little hesitation in using "Melanesia," "Micronesia," and "Polynesia" and argue that the way these terms are used today by many Islanders suggests they have attained a place of emergent authenticity within Islander worldviews. As Margaret Jolly attested, "The terms are deployed in the self-designations and claimed identities of Pacific peoples-'the Melanesian way,' 'the Polynesian triangle,' 'the Micronesian world'" (2007, 52I). Besides this, the boundaries of these regions are blurred by many Islanders, who often do not acknowledge distinct phenotypic differences based on region alone. For example, many Islanders with whom I have spoken perceive population groups within Fiji (particularly Rotuma), Papua New Guinea (particularly the Mortlock Islands), and Solomon Islands (particularly Luangiua) as more Polynesian than Melanesian, with Nauru's population being perceived as a mixture of Melanesian, Micronesian, and Polynesian. Further, some Islanders acknowledge that the regional boundaries of the three zones lack rigidity and that factors such as colonialism have influenced these-such as Kiribati and Tuvalu (formally the Gilbert and Ellice Islands) having both been previously classified as part of Micronesia yet Tuvalu currently being incorporated into Polynesia. Importantly, the use of "Melanesia," "Micronesia," and "Polynesia" offers a quick and easily understood way to establish external boundaries of the Pacific and identify who is a Pacific Islander. 
Throughout this essay, I use "Pasifika" to refer to people of all of Melanesia, Micronesia, and Polynesia, including Australian South Sea Islanders. Elizabeth (a Māori woman living in Australia) was initially hesitant to use "Pasifika" as she believed it applied only to "Island" Polynesia (ie, excluding Melanesia, Micronesia, and New Zealand). However, other Māori people are more open to this term, with Vikki, a Māori community leader in Queensland, arguing that "Pasifika" is "inclusive of all twentysix nations and their descendants, including Māori."

Similarly, I use "Oceania" to include all of Melanesia, Micronesia, and Polynesia. Certainly, the term is embraced by many at the community level. For example, the Pacific Games (formerly the South Pacific Games and likened to the Olympics of the Pacific) are referred to by some Islanders as the Oceanic Games. However, I acknowledge that "Oceania" is also a contested term, with some scholars dividing the region into Near and Remote Oceania, as previously mentioned (D’Arcy 2006, I). Pacific Islander scholars too have objected to the term, arguing that originating outside the Pacific, it is a descriptor reminiscent of colonial relationships of power in the region (Māhina 2010).

In an attempt to redress this, some Pacific scholars have advocated the use of the term "Moana" (a Polynesian word meaning [Great] Ocean) in lieu of "Oceania," "Pasifika," and the "Pacific Islands" (Māhina 20Io). Pacific Islander anthropologist Epeli Hau'ofa was instrumental in using Pacific-based thought and terminology to explain the Pacific world as a sea of islands connected by the water rather than separated by it, as in the initial Western conception of the region (Hau'ofa I993, 6-Io). Ilana Gershon extended this image to include Pacific Islander families within the diaspora and homelands $(2007,474)$. Hūfanga 'Okusitino Māhina in particular argued that as a Pacific-based term, "Moana” more adequately reflects the Islander worldview such as that promoted by Hau'ofa (Māhina 20I0). I do not object to the term, save to posit that as a Polynesian word, its use may serve to alienate Melanesian and Micronesian people who neither use it nor have the word in their home Island's vocabulary. I suggest that the growing academic popularity of "Moana" is testament to the current dominance of Polynesian thought and involvement in matters of the Pacific. The advanced status of Māori and Pacific Islander academic affairs in New Zealand means that that country's sociopolitics of Islander identity heavily influences emergent constructions of Islander panethnicity in international academic settings.

Indeed, historical and contemporary sociopolitical processes shape 
definitions and uses of "Pacific Islander," which vary across state borders and between national and community groups. The concept of an allembracing Pacific Islander identity is questioned by Spickard (2002, 43), who suggested that very few if any Islanders in the United States would self-define as "Pacific Islander Americans." Instead, Spickard argued that Islanders employ identity terms first as Tongans, Samoans, Fijians, and so on and whatever combination of Islander and non-Islander ethnicities they embody, and secondly as Melanesian, Micronesian, or Polynesian $(2002,43)$. Without voiding this assertion (indeed, I recognize its importance in the layering of identities), I suggest that Islanders in Australia often do self-define as "Islanders" and "Pacific Islanders," and that these terms are used in individual, group, and panethnic ways.

\section{Negotiating Pacific Islander “Authenticity”}

Growing up in Australia, my siblings and I quickly became aware that we were not like the "White" kids who grew up around us. Unlike them, we were often asked, "Where are you from?" and "Australia" was not an acceptable response. We knew we were "Black," New Guineans, and Pacific Islanders. We did not realize that some people had a problem with that until, when I was about seven, a bully started chasing my brother and me, throwing rocks at us and calling us the " $n$ " word. It was the first of only a few times my mother ever encouraged us to go back and taunt our tormentor with threats of black magic and cannibalism. Most other times, we were charged with the responsibility of "representing" our "race," by showing respect for ourselves-especially in the ways we behaved, dressed, and spoke-and respect for others. Being an Islander meant that our connection to our "homeland" was unaffected by distance; that we understood things about nature and spirituality others could not; that we had a sense of kinship with other Islanders and other "Black" people. Melanesian, Micronesian, and Polynesian divisions did not apply. Indeed, throughout school, that sense of kinship drew us Islanders together and reinforced our Islander identities.

As with any overarching ethnic or "racial" category (eg, African, European), "Pacific Islander" is a complex and often contested label. The term "Islander" is used synonymously with "Pacific Islander," but usually both are tied inextricably with understandings of "race," identity, and group belonging. Further, certain sets of behavior are perceived to "authenticate" Islander identity; behavior may be subject to greater scrutiny in this 
way during social events where many Islanders are present, and interestingly, the use of "racial" categories are an extension of this. Other times, authenticity may be achieved through demonstrating connection to homelands in various ways. And Islanders may show agency in using self-deprecating stereotypes combined with humor to juxtapose their self-expression with others' perceptions of them. In this section, I highlight actual uses of the terms "Islander" and "Pacific Islander," in order that I can focus on authentic expressions of Islander identity. This will lay the foundation for a deeper understanding of panethnic "Nesian" identity later in this essay.

\section{"Authentic" Behavior}

What does it mean to be an Islander? And how does the Australian-based diaspora shape Islander identity? Linnekin and Poyer explained the construction of Islander identity by asserting that "in Oceanic societies identity is continually demonstrated, a matter of behavior and performance" (I990, 8). In diasporic communities, this behavior may involve visits or remittances to home Islands (Lee 2009, I6), routine association with other Islanders, or adherence to certain cultural practices. For example, when Will (an Islander in his mid-twenties) hosted a barbeque at Tom's house in Queensland, ${ }^{11}$ Tom (an Islander in his early twenties) was embarrassed when Will requested that guests bring their own meat and the food was not pooled for distribution. As a result, guests cooked and ate their own food, separately and at different times from one another. Later Tom complained to some friends, "That's not the Islander way! What's wrong with him? He's such a pālagi [white person]." ${ }^{2}$ Tom (and other Islanders present at the barbeque) had an expectation that as an Islander, Will should have organized the event differently, in line with the Islander practice of sharing food and eating together. In rejecting Will's behavior as pālagi, Tom attempted first to separate himself from Will's actions and second to assert his own identity as an Islander. Essentially this demonstrates that Islander identity is strengthened by adhering to a certain set of behaviors. More than that, there is among Islanders an awareness of difference and a disappointment if an Islander chooses to deviate from group expectations.

However, what constitutes behavior demonstrable of Islander identity is sometimes contested. Jess (an Islander in her early thirties) explained her preference to not associate with other Islanders: "There's just too much politics. They gossip too much and bitch about you behind your back. I just don't want to be that kind of Islander." Within some social circles, the perception of people like Jess who reject group participation and politics 
is that "they think they're too good to hang out with us. She's Islander, but she thinks she's a misis [white woman],"13 as argued by Mandy (an Islander in her mid-thirties). In this situation, I argue that both Jess's allies and those whom they socially reject perceive each other as "Islanders behaving badly" rather than as "non-Islanders." For example, if Jess and Will (from the examples above) were truly perceived as non-Islanders, no one would scorn them for not behaving as Islanders should. However, in drawing comparisons between "Islanders behaving badly" and members of non-Islander identities (eg, pālagi and misis), the implication is that Islander identity is perceived as being authenticated and negotiated through certain behaviors.

\section{Appearance and "Race"}

Perceptions and negotiations of "race" may be used as part of the authentication process of Islander identity, particularly in terms of "Black" and "White." Some background to this phenomenon may rest in the historically Westernized racial hierarchy that privileged "aesthetically pleasing," "morally superior" Polynesians and looked down on "darker-skinned," "uncivilized" Melanesians (D’Arcy 2003, 2I 8). Intellectual adherence to this hierarchy (even in a joking manner) can lead to negative comparisons between and by Melanesians, Micronesians, and Polynesians. For example, I have witnessed some Melanesians respond to Polynesian adherence to this hierarchy with assertions that Polynesians are arrogant and, significantly, that Melanesians are "cooler" because they are "Black" and Polynesians only want to be. Interestingly, despite this tension, a "Brown" identity, much like that described by Caroline Brettell and Faith Nibbs (2009), is sometimes used in invoking Islander panethnicity. But how much of the "race" of an Islander is actually determined by appearance?

Nina (a Papua New Guinean in her late twenties) was talking about her friends: three brothers of Papua New Guinean, Tuvaluan, and Samoan descent. Nina posited that the eldest brother, Lenny, looked like his mix of Islander heritage (ie, he looked equally Papua New Guinean, Tuvaluan, and Samoan); the middle brother, Max, looked "pure" New Guinea Islander; and the youngest brother, James, looked the most "like an Islander." In this case, Nina's use of "Islander" referred to her perception of James's appearance portraying only his Polynesian heritage. So, in this example, perceived phenotype was important, and the single term "Islander" was used synonymously with "Polynesian." Note also, though, that in this example, although phenotype was important, "race" was not essentialized 
in terms of color, since Lenny rather than James had the lightest skin of the three brothers.

I have noted how notions of cultural "Whiteness" (eg, identities such as pālagi and misis) are verbalized and applied when people are perceived to have deviated from what is thought to be expected Islander behavior. The same is applied to notions of someone's connection to place, whether that is the diasporic setting or the homeland. For example, when Elena (an Islander in her mid-twenties) visits her home in Sāmoa, she feels that being called pālagi is derogatory and that because she is "mixed" (Samoan and "White") and because she has spent much of her life in Australia instead of Sāmoa, she is ostracized, or seen differently, as "not enough" of an Islander. In a similar way, notions of "Blackness" are also invoked. Jay (a New Guinea Islander in his twenties), asserted, "We [Islanders] need to look good when we go out. We're 'Black,' we need to represent!' Conversely, when Alex (a Tuvaluan in his late twenties) began to liken himself to African Americans, his friends (from a mix of Islands) remarked, "He's not 'Black,' he's an Islander." However, Carol (an Islander in her fifties) had experience that adds some justification to Alex's identification in that way: "I'm mixed-race. At home [Papua New Guinea] they call me 'White.' But in Australia, I'm 'Black." As Marianne Franklin explained, Islanders use notions of "race" in relation to social "networks and obligations" both in the "home" Islands and in the diaspora $(2003,466)$. This is an example of an "open-ended reading of how 'race' operates as a trope" in conversations and everyday lives (Franklin 2003, 472). "Race" is used as "shorthand for physical, attitudinal and cultural commonality on the one hand, and as a call for pride, self-awareness, and the right to be distinct on the other" (Franklin 2003, 472). Further, she argued that this is "an elastic term for a human condition that is to be examined rather than denied or reified" (Franklin 2003, 472).

\section{Stereotypes and Humor}

Some people also use negative stereotypes in an ironic way to express their Islander identity. One hot day in Queensland, Darlene and I got into our car, which had been sitting in the sun in a car park for most of the day. We were already sweating as we struggled with the air-conditioning and could not understand why, despite our efforts to put the control toward the "+" mark, the air was not getting cool. Eventually (after cursing the air-conditioning unit for being broken), we realized that the "+" indicated that the temperature rather than the air-conditioning's icy strength would 
be increased; we had been effectively turning on the heater. We laughed at our mistake and Darlene remarked, "Typical Islanders!" Darlene was invoking a stereotype of Islanders as unsophisticated. ${ }^{14}$ Drawing out this stereotype was humorous because it juxtaposed not only with our high levels of formal education but also with our understanding that Islanders cannot be wholly categorized as such. At the same time, acknowledging this stereotype (used by and about Islanders) reinforced our Islander identity.

Just as Gillian Cowlishaw described how Aboriginal people in New South Wales use and invoke derogatory stereotypes of themselves in situations that establish performance of roles between "insiders" and "outsiders" (200I, 2004), this example provides evidence of the same. What appears to be self-deprecating is actually an act of "Black" agency and empowerment and establishes the "players" in their various roles, but with an edge of irony that inverts these stereotypes. Similarly, Georgina Tsolidis and Vikki Pollard described the ways in which members of Melbourne's Greek community self-identify through using the traditionally derogatory term "wog" in new and ironic ways that both strengthen their cultural identities and critique the term's racist associations (2009, 430$43 \mathrm{I}$ ). In the same manner, the following vignette also demonstrates use of stereotype and Islander agency.

In 2008, Penny (a New Guinea Islander in her early thirties), her mother, and her grandmother were at a cafe on Queensland's Sunshine Coast. She reported that the three of them stood there for a while without being served. Eventually, the shop attendant appeared from the back room and, by this time, other customers had entered the store. The shop attendant looked at Penny and her family on her way over to the other customers. After she served the other customers, using the register that Penny and her family were standing in front of, the shop attendant looked at them but did not ask if they needed any help. Penny's mother laughed and joked about whether the store had an official policy for not serving "Black" people. She then added, tongue-in-cheek, "We're just happy little Islanders." In this example, Islanders were self-stereotyped as "happy little Islanders," willing to put up with being ignored while maintaining a pleasant demeanor. However, this was juxtaposed by Penny's mother's comment about the store's official policy and the simultaneous implication that the store worker was being racist-an assertion reminiscent of colonial-era politics that placed the status of "White" people above that of "Black." 
People are positioned in various roles according to "racial" stereotypes. Panethnic identities are solidified in diasporic settings and, in my experience as an Islander, the use of stereotypes in this way is relatively common. This is evidenced, whether in the form of "Black" agency for inverting negative stereotypes in juxtaposition to other sociocultural aspects, or in contexts where Islanders invoke more benevolent stereotypical Islander concepts and material culture-eg, mumu (Papua New Guinean earth oven); muumuu (Hawaiian "traditional" dress); sulu (Fijian sarong); aloha shirts; leis-to invoke manifestations of Islander identity. Diasporic Islander identity is foregrounded in multiple ways: through connecting to place, for example, "Salim tingting long peles" (Tok Pisin: homesick thinking about place); material culture; association with other Islanders (whether or not these are people from the same Island); and behavior. Indeed, diaspora politics may show a two-way effect between diasporic and homeland groups, with each one influencing the other just as much (Shain 2002). Remittances and home visits are examples of this. Through the active use of stereotypes, a set of practices acquires emergent authenticity among the diasporic groups and panethnically.

\section{Connections to "Home"}

I have already mentioned how remittances and reverse mobility strengthen Islander identity. ${ }^{15}$ The following example illustrates this assertion. Catherine was born and grew up in Australia and claims identity as Islander, drawing heritage from Papua New Guinea. When Rob introduced her to Eugene (both New Guinea Islanders) at a birthday party, Eugene later commented, "But she's never even been to her island. She's not an Islander." For Eugene, this type of reverse mobility is vital to the acquisition of Islander identity. Despite previous research (and my own experience) indicating the irrelevance of birthplace and location, and the significance of intangible connections to peles (McGavin 2007), Eugene's comments reinforce the importance of place while strengthening the idea that Islanders need to perform certain tasks or display certain behaviors in order to solidify their identities. Indeed, a strong connection to place-even if this is a transnational notion or "intragroup memory" of an "imagined," stereotypical home Island (eg, through stories, memories, photographs, and material culture)-is very important in diasporic settings (Kissau and Hunger 2010, 246-247; Landzelius 2006, 3; Mageo 200I, I I-I 8). As highlighted earlier, many Islanders visit the Islands not as tourists but as a part of a "homecoming" that strengthens their identity. 
In Catherine's case, learning that she represents Papua New Guinea in international sport subsequently lessened Eugene's idea of her not belonging. ${ }^{16} \mathrm{He}$ perceived her involvement in representing her Island "home" as strengthening her connection to place and therefore authenticating her identity as an Islander.

\section{Summary}

As demonstrated, invocation of the categories "Islander" and "Pacific Islander" occurs in informal conversations between Islanders and with others, during social interactions, and throughout everyday and more formal occasions. Utterances of "Islander" and "Pacific Islander" in Australia often play on stereotypes, whether tongue-in-cheek or otherwise. In many cases, a dichotomy of self and other is created. Whether this aligns with notions of (I) "I am an Islander and you are not" or (2) "you and I are both Islanders," there is a fluctuation in the perceived authenticity of Islander identity. The meanings of "Islander" and "Pacific Islander" are negotiated in different ways and vary according to situation, aligning with Roosens's assertion that expression and interpretation of ethnicity is flexible (I989, I7-I 8). As previously mentioned, Barth contended that ethnic groups have dynamic "internal" cultural content and boundaries; he argued that groups and their boundaries thrive in conditions in which ongoing interaction between "self" and "other" occurs (I998, 6, I0). This might explain why, in my vignettes, when group membership was questioned, labels of nonmembership (eg, pālagi and misis) were invoked. In the same fashion, Brettell argued that the formation of ethnic groups is not inevitable but relies on circumstance (2003, I09).

\section{Panethnic Islander Identities}

I met Andrew (an Islander in his late thirties) at a Pasifika festival north of Brisbane in 20I 2. When asked to describe his ethnic background, Andrew said, "I'm a true Islander-I'm a fruit salad." He explained that his mother was Cook Islands Māori, his father was Samoan, he had lived in Fiji and New Zealand, and he was married to a Māori. I have heard this fruit salad analogy used many times to describe Islander identity. Its parts (signifying national identity such as Samoan or Cook Islands Māori) remain intact despite their combination constituting a new, enveloping identity (ie, Islander), in the same way Pearson's "layers of identity" describes the shifting prominence of various layers of identity among Aboriginal peo- 
ple in Australia (2006). Importantly, the fruit salad analogy is also commonly used by Islanders to self-define as a panethnic group in situations in which there are many Islanders (from different "home" Islands) gathered together, formally or informally. These two different uses of "fruit salad" are representative of what Sharp called the "fluid and hybrid character" of identities that are sociopolitically negotiated in both panethnic and multiethnic ways (I997, I6). That is, the layered facets of "Pacific Islander" not only include multiethnic or "multiracial" identity but also provide an umbrella term to group together various nation-based identity categories.

Exploring "Islander" and "Pacific Islander" as panethnic labels highlights the ways in which these terms are used in everyday circumstance by the people the terms are intended to describe. Examining the instances in which Islander identity subsumes its localized context and starts to embrace the global establishes a framework of understanding around the sociopolitics of these terms. Such cases often involve the need for various Island groups to work together in order to achieve a social or political goal that would benefit all participants. Indeed, it is in the nature of diasporic groups to do so (Eriksen 2002, 53). Of great importance to panethnic Islander identity is that Islanders often maintain a "unity in diversity" approach, rejecting the homogenization of the group; in large part, this is the key to being "Nesian."

Although the use of the term "Nesian" is concentrated in groups of younger people (primarily those heavily engaged in social media), the same sentiment is expressed by community leaders of various Island groups at Pasifika meetings, specifically those held by the Pacific Youth Association of Queensland (PYAQ), with which I am involved. Elders at one of the early meetings of the organization argued that despite the cultural and linguistic differences between Pacific groups, our similarities as Islanders (particularly our shared practice of the "Pacific Way") give cause for our unification, and that as Islanders we could enact positive change for our youth and communities. Indeed, PYAQ recognizes that within the diaspora it may be difficult for young Islanders to maintain practical connections to "traditional" customary practices. For this reason one of PYAQ's missions is to create spaces and events where young Pacific Islanders are able to strengthen their Islander identities through building connections with elders from all Pasifika groups, especially in relation to "traditional" customary practices. This type of panethnicity, like ideas about "Nesian" identity, is formed through an ideal of "unity in diversity" and justifies 
and constructs a panethnic Islander identity especially valid within diasporic settings.

Indeed, notions of "unity in diversity" are common in diasporic communities in order for members to achieve political goals (Eriksen 2002, 53). The very notion of diasporic communities suggests that the "primary identity [of peoples forming a diaspora] connects them to their ancestral country, even if they have lived their entire lives elsewhere" and this identity is arguably strengthened in causes of social, political, or civil rights (Eriksen 2002, I 52). In this manner, the following example highlights the unifying effect of diasporic settings and the reterritorialization of identity online.

\section{Interactions in Diaspora (including Cyberspace)}

In 2008, at the "Being 'In-between': Projects Engaging Second Generation Young People" conference, social researcher Liza Hopkins argued that young people (across ethnic categories) who form diasporic communities in Australia and elsewhere undergo a process of deterritorialization and reterritorialization in relation to their ethnocultural identities. Hopkins posited that, in doing so, youth from diasporic communities claim multiple identities through the disassociation of identity with particular spaces or places and the reterritorialization of ethnic identity into virtual spaces, that is, online (pers comm, 2008). Camilla Gibb agreed: "In the deterritorialized space of cyberspace ... [people] are invoking a new language of nationhood in order to give shape to a now-dispersed community" (2006, I70). Indeed, I suggest that the increasing use of social networking technology such as Facebook, Myspace, and Bebo (known colloquially to some younger Islanders I spoke to as "Island Facebook") means that there are online communities of like people, virtual spaces where people support, strengthen, and negotiate their ethnocultural identities (McGavin 2008). Further, I contend that, with the use of this technology, younger people find "a reduced need to associate a traditional ethnic identity with time spent in an actual place, as the online community can be accessed and interacted with, at any location in the world where there is access to the internet" (McGavin 2008). A prime example of this can be found in the forwarded e-mails, online interactive forum games, and Facebook pages that specify "insider"-generated stereotypical criteria for particular ethnic identities. For example, "You know you're Samoan when ..." is an online forum thread that enables users to respond to this topic by completing the sentence begun in its title. Responses include: 
"You have a whole pile of shoes blocking the entrance at the door" and "you make that funny kissing sound with your lips to try and get someones attention.” (Posted by user "krusty_phob,” 2006)

"When you have 2 or more pictures of Jesus in your house" and "you use a ie lavalava [sarong] for your curtains." (Posted by user "TeineMalosi," 2006)

There are similar interactive forums based upon other Pacific Islander identities also, often with like responses:

"You have sat in a 4-seater car with up to 8 other people"; "You make that funny kissing sound with your lips when you're trying to get someone's attention"; "You can speak with your face-eg, twitch like a rabbit to ask, Where you going?"; and "Your Grandmother thinks Vicks Vapo-Rub is the miracle cure for everything (including broken bones )." (Posted in response to "You know you're Papua New Guinean when ...” by user "Kofi Kwin,” 2005)

"Ur Mother says that at 25, u'r too young to have a boyfriend"; "U have a big velvet picture of The Last Supper in your living room"; "U run into a mountain of shoes blocking the front door to the house"; "U go to the islands rich and come back poor"; and "U know the difference between all the different types of corned beefs!" (Posted in response to "You know you're Fijian when ..." by user "Caginitoba," 2010) ${ }^{17}$

The penultimate assertion in the last quote (" $U$ go to the islands rich and come back poor") is particularly telling that such forums are used primarily by people within diasporic communities. Such forums provide young people not only with links to a like online community but also with the opportunity to check off the list of their own attributes, and thereby authenticate their own identity as Islanders. These Islanders' representations of themselves are both positive and negative; overall they tend to present similar themes to other Islander forums. These similarities are evidenced in the above selection of quoted responses, including expressions of Christianity, the practice of removing shoes before entering a house, a perceived lack of sophistication, and the use of nonverbal communication. Indeed, some forums listed exactly the same points as other Islands in response to their own Island identity. These websites embody the reterritorialization that Hopkins described (pers comm, 2008) and provide evidence of the various and emerging ways in which panethnic Islander-or "Nesian"-identities in the diaspora are strengthened.

\section{Cultural Practices and Language}

In early 20I 2, I attended a planning meeting for a Pasifika conference to be held in Australia. "I'm not religious," remarked Lani (a Māori woman 
in her early forties), "but if we're going to do this right-the Islander way-then we have to open with a prayer." Prayer is a common trope used by Islanders to invoke Islander identity. Language is another, and the roots of this lie in home countries where, if your Island is your "motherland," then your language is the umbilical cord (McGavin 2007).

Language connects people to their peles, but if they cannot speak their language, people make up for this in various ways, such as through the use of stereotypes of "Islanderness" and through fictive kinship (although these things are also used to assert Islander identity regardless of the level of language acquisition). For example, Marlon (a Tuvaluan in his midtwenties) often greets people with the Hawaiian term "aloha." He knows a little of his own language and he certainly knows "talofa" (Tuvaluan "hello"), but he uses aloha because it is arguably more universally known. In the diaspora, Islanders share vocabulary from across the Islands and use stereotypical Island concepts to strengthen Islander identity within and across "traditional" Island group boundaries. Indeed, I have observed a panethnic understanding and use of a variety of inter-Island terms. "Mumu" (usually spelled "muumuu") is often used to refer to the colorful, loose, smock-style dress popular in the Islands, but it is also a term used in Papua New Guinea to describe a traditional earth-oven style of cooking. (The Island-style dress is called a "meri blaus" in Papua New Guinea.) In this manner, "hangi" (Māori), "umu" (Sāmoa), "lovo" (Fiji), and "mumu" (Papua New Guinea) are used and understood widely as "traditional" methods of cooking using an earth oven. Similarly, "lavalava" (parts of Polynesia), "laplap" (Papua New Guinea), and "sulu" (Fiji) —all terms referring to a sarong-type garment—are often used interchangeably by individual Islanders with whom I spoke.

Fictive kinship involves associating with other Islanders and (despite there being no consanguinity or affinal relationship) referring to them as your sista, brother, cousin, aunty, uncle, and so on, as appropriate. This is not just a way to overcome lack of knowledge of Island language but is employed in various circumstances regardless of language acquisition. Lulu (originally from Fiji) moved to Australia with her family more than twenty years ago. She told me she grew up in a small city in Queensland, where there were not many "Black" people, let alone Islanders. She befriended some other (mainly South Sea and New Guinea) Islanders and they all called each other cousin, brother, and sister. However, this became a problem when romantic relationships began to develop between the girls and the boys in the group as they got older. They had to stop calling each 
other "brother" and "sister" and "cousin" and explain to everyone else that they were not actually related, that that was just "something Islanders do."

\section{Summary}

As shown in the above vignettes, panethnic Islander identity emerges as part of social identity and strengthens Islander identity especially in terms of connecting to place (whether real or virtual). This is an especially relevant point, considering that connection to place (or peles) is also a customary way of expressing Islander identity, especially in Melanesia (McGavin 2007). Within diasporic communities, certain elements of Pacific material and intangible culture have come to attain a status that symbolizes and strengthens both home Island and panethnic Islander identity (eg, men's and women's hula; muumuus; laplaps; flowers worn in the hair). The idea that some elements of material or intangible culture may be appropriated from Islander cultures other than the actor's own-a process that Erich Kolig has described as "re-traditionalisation" $(2002,8)$-is significant in two main ways. First, this is an expected part of the panethnic "Nesian" identity, where previous boundaries between Island nations become blurred and permeable. Second, it is testament to the difficulties faced by some diasporic communities: the restricted availability of elders to serve as teachers of specific home Island dances and other practices; the limited access to authentic materials with which to construct "traditional" dress; and the lack of time or opportunity to impart certain types of cultural knowledge from individual home Islands to younger generations. Smaller communities with like attributes pool their resources in aid of the larger group. In this way, Islanders' ideas of panethnic Islander identity align with the idea of "unity in diversity," a notion described by some Islanders as "fruit salad."

\section{Conclusion: Being "Nesian"}

Chris Tilley argued, "The manner in which identities are produced and sustained needs to be understood within frameworks of power relations, dominance and resistance, and their relation to different kinds of knowledge, 'Western' and 'Indigenous'”(2006, I 5). Certainly, this can be said of Pacific Islander identity in Australia, but specifically in relation to ideas about "race," place, and belonging. Insider anthropology has shaped this essay, and as its author, I have drawn on my own socialization as 
an Australian of Pacific Islander descent to reinforce many of the data I have presented herein. I have shown that Islander identity is negotiated in both subconscious and consciously strategic ways by Islanders in order to achieve sociopolitical goals. Various cues, including material culture; speech, accent, and choice of words; behavior; and outside circumstance prompt assertions of Islander identity and may indicate a broader panethnicity and interconnectedness with other Islander groups. In this way, the terms "Islander" and "Pacific Islander" are invoked to authenticate a person's Pasifika identity and may simultaneously be used to question someone else's.

Use of the terms "Islander" and "Pacific Islander" is infused with social politics even within Islander groups. These terms underscore individual and group membership and belonging in both cultural and ethnic terms and not only reflect the boundaries of these groups but actively shape and reshape them. Indeed, the ways in which Pacific Islanders in Australia express their sense of belonging highlight an ongoing connection to a Pacific homeland as well as to Australia. However, the degree to which a person is perceived as belonging in a certain placewhether Island or Australia-is sometimes challenged, by both Islanders and non-Islander Australians. Pearson's description of these multiple belongings as shifting "layers of identity" is particularly apt (2006). Pacific Islander communities in Australia are growing. Appropriation of broader Pacific culture shows an emergent authenticity of ethnicity through which individual Islander identities are strengthened and panethnicity is simultaneously reinforced. Panethnic Islander identities do not negate ethnic categories of belonging but exist alongside them. In keeping with that notion, this essay has offered some contemporary insight into the relationship between these identity categories in a diasporic setting and where diversity and flexibility maintain positions of localized and regional importance.

I WISH TO ACKNOWLEDGE funding support for this research from the University of Queensland, Professor David Trigger, and Ms Lesley Bryant. Discussions with David Trigger and other colleagues in anthropology at the School of Social Science, University of Queensland, have provided an excellent intellectual setting in which to pursue this project. My thanks also to the anonymous reviewers of this essay, who provided insightful and encouraging feedback on an earlier draft. 


\section{Notes}

I These lyrics are from the song "Pacific Islands," featured on the I997 album, Pacific Islands: We Are One.

2 I use Pacific Islander "diaspora" to refer to people of Pacific Islander descent who live outside of their "home" Islands, eg, people of Tuvaluan descent living in Australia.

3 Throughout, pseudonyms are used in place of personal names to protect anonymity.

4 Australian South Sea Islanders are the Australian-born descendants of the Pacific Islanders from a range of countries (including but not limited to Kiribati, Papua New Guinea, Sāmoa, Solomon Islands, Tuvalu, and Vanuatu) who came to Australia as forced or indentured plantation laborers in the mid to late nineteenth century (MADASSIA 2000, 2; Miller 20I0; Moore 200I, I67).

5 "Nesian" is a term drawn from the regional names Melanesia, Micronesia, and Polynesia and is pronounced as it is within these broader forms. According to Heather Lotherington (I998, 65-66) and Douglas Oliver (I989, I 5), the respective Greek roots of these terms are black islands, small islands, and many islands.

6 Panethnic identities can emerge from within "homelands" and are not necessarily predicated on diasporic settings; for instance, Pauline Strong and Barrik Van Winkle have discussed Native American panethnic identity (I996).

7 "Peles" is a Papua New Guinean term referring to place of Indigenous origin. The concept, popular in many parts of the Pacific, especially Melanesia, is not limited to landscape but also includes seascape, starscape, spiritscape, etc (McGavin 2007, 218).

8 In this study of the Pacific Islander diaspora, I do not include Torres Strait Islanders, because of their classification as Indigenous. However, I acknowledge that in non-Australian diasporas, Torres Strait Islanders may identify as Pacific Islanders.

9 I acknowledge that some academics (eg, Fenton 2003, 5I-54) prefer not to use the term "race" and therefore, I problematize its usage.

Io Ben earlier mentioned that Māori people and culture related closely to people and cultures across the Pacific including Fiji, Hawai'i, Sāmoa, Tahiti, Tonga, and Tuvalu.

I I To preserve anonymity, I do not state which (different) Islands Will and Tom are from.

I 2 "Pālagi" is a Samoan and Tuvaluan term used throughout parts of Polynesia and in diasporic communities from across the Pacific.

I 3 "Misis" is a term used throughout Papua New Guinea and within diasporic communities.

I4 The term "Fов" (Fresh Off the Boat), often used in a derogatory way among and about Islanders, also plays on this stereotype. 
I 5 "Reverse mobility" is a term first used in relation to migration in a 20 I I session led by Helen Lee and John Taylor at the Association for Social Anthropology in Oceania (ASAO) annual conference.

I 6 I know of several cases in which diasporic Islanders represent or have been asked to represent home Islands in sport. For example, Drake (a Tuvaluan in his mid-twenties who has lived in Australia for thirteen years) told me he has been asked at least three times during that period to internationally represent Tuvalu in tennis.

I7 Discussions like these are online at MYFIJIFRIENDS.COM (http://online .myfijifriends.com/profiles/blogs/you-know-youre-a-fijian-when [accessed 29 Nov 20I0]); PNGINUSA.ORG (You know you're Papua New Guinean when: http://www.pnginusa.org/forums/index.php?showtopic=206 [accessed $23 \mathrm{Nov}$ 20I0]); and SAMOANWORLD.COM (You know you're Samoan when: http:// www.samoaworld.com/viewtopic.php?t=86 [accessed 2I Nov 2010]) as well as on Facebook (https://www.facebook.com/pages/You-know-youre-SAMOAN -when/I 2959775707505 I [accessed Io Sept 20I3])

\section{References}

Anae, Melani

20го Teu Le Va: Toward a Native Anthropology. Pacific Studies 33 (2): 222-240.

Barth, Fredrik

I998 Ethnic Groups and Boundaries: The Social Organization of Culture Difference. Prospect Heights, IL: Waveland Press.

Bolles, A Lynn

$200 \mathrm{I}$ Seeking the Ancestors: Forging a Black Feminist Tradition in Anthropology. In McClaurin 200I, 24-48.

Brettell, Caroline

2003 Anthropology and Migration: Essays on Transnationalism, Ethnicity, and Identity. New York: Altamira Press.

Brettell, Caroline, and Faith Nibbs

2009 Lived Hybridity: Second-Generation Identity Construction through College Festival. Identities: Global Studies in Culture and Power I 6 (6): 678-699.

Bruner, Edward, and Victor Turner, editors

I986 The Anthropology of Experience. Chicago: University of Illinois Press.

Clark, Geoffrey

2003 Dumont d'Urville's Oceania. The Journal of Pacific History 38 (2): I 5 5-I 6I. 
Connell, John

2006 Nauru: The First Failed Pacific State? The Roundtable: The Com-

Cowlishaw, Gillian monwealth Journal of International Affairs 95 (383): 47-63.

200I Performing Aboriginality: The Politics and Poetics of Citizenship in Everyday Life. UTS Review 7 (I): I 53-I69.

2004 Blackfellas, Whitefellas and the Hidden Injuries of Race. Carlton, vic: Blackwood Publishing.

D’Arcy, Paul

2003 Cultural Divisions and Island Environments since the Time of Dumont D'Urville. The Journal of Pacific History 38 (2): 217-235.

2006 The People of the Sea: Environment, Identity, and History in Oceania. Honolulu: University of Hawai'i Press.

Eriksen, Thomas Hylland

2002 Ethnicity and Nationalism. London: Pluto Press.

Fenton, Steve

2003 Ethnicity. Cambridge, UK: Polity Press.

Franklin, Marianne

2003 I Define My Own Identity: Pacific Articulations of "Race" and "Cul-

Gershon, Ilana ture" on the Internet. Ethnicities 3 (4): 465-490.

2007 Viewing Diasporas from the Pacific: What Pacific Ethnographies Offer Pacific Diaspora Studies. The Contemporary Pacific I9:474504 .

Gibb, Camilla

2006 Deterritorialized People in Hyperspace. In Native on the Net: Indigenous and Diasporic Peoples in the Virtual Age, edited by Kyra Landzelius, 55-67. London: Routledge.

Gilliam, Angela

200I A Black, Feminist Perspective on the Sexual Commodification of Women in the New Global Culture. In McClaurin 200I, I 50-I 86.

Harrison, David

2004 Tourism in Pacific Islands. Journal of Pacific Studies 26 (I): I-28.

Hau'ofa, Epeli

I993 Our Sea of Islands. In A New Oceania: Rediscovering Our Sea of Islands, edited by Eric Waddell, Vijay Naidu, and Epeli Hau'ofa, 2-I7. Suva: University of the South Pacific School of Social and Economic Development.

Jolly, Margaret

2007 Imagining Oceania: Indigenous and Foreign Representations of a Sea of Islands. The Contemporary Pacific I9:508-546. 
Kauanui, J Kēhaulani

2007 Diasporic Deracination and "Off-Island" Hawaiians. The Contemporary Pacific I9:137-I60.

Kayser, Manfred

2009 The Human Genetic History of Oceania: Near and Remote Views of Dispersal. Current Biology 20 (4): I94-20I.

Kissau, Kathrin, and Uwe Hunger

2010 The Internet as a Means of Studying Transnationalism and Diaspora. In Diaspora and Transnationalism: Concepts, Theories and Methods, edited by Rainier Baubock and Thomas Faist, 245-266. Amsterdam: Amsterdam University Press.

Kolig, Erich

2002 Introduction: Cultural Revival, The Construction of Indigeneity, and the World-System. In Politics of Indigeneity in the South Pacific, edited by Erich Kolig and Hermann Muckler, 7-24. London: Transaction Publishers.

Landzelius, Kyra, editor

2006 Native on the Net: Indigenous and Diasporic Peoples in the Virtual Age. London: Routledge.

Lee, Helen

2009 Pacific Migration and Transnationalism: Historical Perspectives. In Migration and Transnationalism: Pacific Perspectives, edited by Helen Lee and Steve Tupai Francis, 7-4I. Canberra: ANU E Press.

Linnekin, Jocelyn, and Lin Poyer, editors

I990 Cultural Identity and Ethnicity in the Pacific. Honolulu: University of Hawai'i Press.

Lotherington, Heather

I998 Trends and Tensions in Post-colonial Language Education in the South Pacific. International Journal of Bilingual Education and Bilingualism I (I): 65-75.

MADASSiA, Mackay and District Australian South Sea Islander Association 2000 Protocols Guide: Drumming the Story: It's Our Business! Mackay, QLD: Payne Print.

Mageo, Jeannette, editor 200I Cultural Memory: Reconfiguring History and Identity in the Postcolonial Pacific. Honolulu: University of Hawai'i Press.

Māhina, Hūfanga 'Okusitino

20ıо Tā, Vā, and Moana: Temporality, Spatiality, and Indigeneity. Pacific Studies 33 (2): I68-202.

McClaurin, Irma, editor $200 \mathrm{I}$ Black Feminist Anthropology: Theory, Politics, Praxis, and Poetics. New Brunswick, NJ: Rutgers University Press. 
McFarlane, Tracy A

2010 Experiencing Difference, Seeking Community: Racial, Panethnic, and National Identities among Female Caribbean-Born U.S. College Students. American Review of Political Economy 8 (2): 87-I I4.

McGavin, Kirsten

2007 Tourism, Gender and Ethnicity in West New Britain: The Challenges and Dynamics of Islander Identities. PhD thesis, anthropology, University of Queensland.

2008 First Generation Australian or Second Generation Migrant: Youth Identity in the Third Space. 7 March. Available on the Youth Affairs Network of Queensland website: http://www.yanq.org.au/Io/post/ 2008/03/first-generation-australian-or-second-generation-migrantyouth-identity-in-the-third-space.html [accessed 30 Aug 20I3]

Miller, Imelda

20I0 Sugar Slaves. 22 October. Available on the Queensland Historical

Atlas website: http://www.qhatlas.com.au/content/sugar-slaves

Moore, Clive [accessed 20 May 2012]

200I The South Sea Islanders of Mackay, Queensland, Australia. In Endangered Peoples of Oceania: Struggles to Survive and Thrive, edited by Judith Fitzpatrick, I67-I82. Westport, СT: Greenwood Press.

Oliver, Douglas

I989 The Pacific Islands. Third edition. Honolulu: University of Hawai'i Press.

Pearson, Noel

2006 Layered Identities and Peace. Speech given as part of the Earth Dialogues at the Brisbane Festival, 23 July. Available on the Cape York Institute website: http://cyi.org.au/wp-content/uploads/20I I/o9/2 -2oLayered-2oIdentities-2oand-2oPeace.pdf

Perez, Michael

2002 Pacific Identities beyond US Racial Formations: The Case of Chamorro Ambivalence and Flux. Social Identities: Journal for the Study of Race, Nation and Culture 8 (3): 457-479.

Ricort, Milagros, and Ruby Danta

2003 Hispanas de Queens: Latino Panethnicity in a New York City Neighborhood. New York: Cornell University Press.

Roosens, Eugeen

I989 Creating Ethnicity: The Process of Ethnogenesis. London: Sage Publications.

Schubert, Mark

2009 Griffith's Transnational Fijians: Between the Devil, the Deep Blue Sea... and Their Pastors. In Migration and Transnationalism: 
Pacific Perspectives, edited by Helen Lee and Steve Tupai Francis, I33-I4I. Canberra: AnU E Press.

Shain, Yossi

2002 The Role of Diasporas in Conflict Perpetuation or Resolution. The SAIS Review of International Affairs 22 (2): I I 5-I 44.

Sharp, John

I997 Beyond Exposé Analysis: Hybridity, Social Memory and Identity

Politics. Journal of Contemporary African Studies I 5 (I): 7-2 I.

Sheppard, Peter

20I I Lapita Colonization across the Near/Remote Oceania Boundary. Current Anthropology 52 (6): 799-840.

Slocum, Karla

200I Negotiating Identity and Black Feminist Politics in Caribbean

Research. In McClaurin 200I, I 26-I49.

Smith, Linda Tuhiwai

2004 Building Research Capacity in the Pacific, for the Pacific and by

Pacific Peoples. In Researching the Pacific and Indigenous Peoples:

Issues and Perspectives, edited by Tupeni Baba, 'Okusitino Māhina,

Nuhisifa Williams, and Unaisi Nabobo-Baba, 4-I6. Auckland: Centre for Pacific Studies.

Spickard, Paul

2002 Pacific Islander Americans and Multiethnicity: A Vision of America's

Future. In Pacific Diaspora: Island Peoples in the United States and Across the Pacific, edited by Paul Spickard, Joanne Rondilla, and Debbie Hippolite Wright, 40-55. Honolulu: University of Hawai'i Press.

Strong, Pauline, and Barrik Van Winkle

I996 Indian Blood: Reflections on the Reckoning and Refiguring of Native

North American Identity. Current Anthropology I I (4): 547-576.

Sydney Morning Herald

20I I Gillard Downplays Solomons Solution. 28 May. http://www.smh .com.au/national/gillard-downplays-solomons-solution-20 I I 0528

- If geu.html [accessed I I Nov 20I2]

Tagata Pasifika

2007 New Zealand-Born Pacific Islanders. 25-minute video from TV New

Zealand. I 8 July. http://www.youtube.com/watch?v=y8u_lTQropo [accessed 3I May 20I3]

Tengan, Ty P Kāwika, Tēvita O Ka'ili, and Rochelle Tuitagava'a-Fonoti

20 I0 Genealogies: Articulating Indigenous Anthropology in/of Oceania.

Pacific Studies 33 (2): I39-I67.

Tilley, Chris

2006 Introduction: Identity, Place, Landscape and Heritage. Journal of Material Culture I I (7): 7-32. 
Tsolidis, Georgina, and Vikki Pollard

2009 Being a "Wog” in Melbourne: Young People's Self-Fashioning through Discourses of Racism. Discourse: Studies in the Cultural Politics of Education $30(4): 427-442$.

Wetherall, David

2002 Teachers All: Samoan, Fijian, and Queensland Melanesian Missionaries in Papua, I884-I9I4. The Journal of Religious History 26 (I): 78-96.

\begin{abstract}
Pacific Islanders in Australia use the terms "Islander" and "Pacific Islander" in many ways and in different circumstances to define themselves and others. Through invoking discourses including these terms, Pacific Islanders both consciously draw on "panethnicity" and subconsciously strengthen and support their localized identities. In this way, Pacific Islanders blur the ethno-cultural and sociopolitical boundaries that traditionally separate groups with connections across a diverse range of countries. Indeed, diasporic settings give rise to transnationalist sentiment and actions and serve to strengthen panethnic identity. Using insider and auto-anthropology and ethnographic research techniques, I draw on my experiences as an Australian of Pacific Islander descent and use examples drawn from my involvement in formalized community groups, cultural events, and social functions. In doing so, I argue that the expression of Islander and Pacific Islander identity is entwined with ideas about "race," place, stereotypes, and behavior that highlight the dynamic ethnogenesis of this group.
\end{abstract}

KEYWORDS: Pacific Islanders, identity, panethnicity, insider anthropology, Australia, transnationalism 

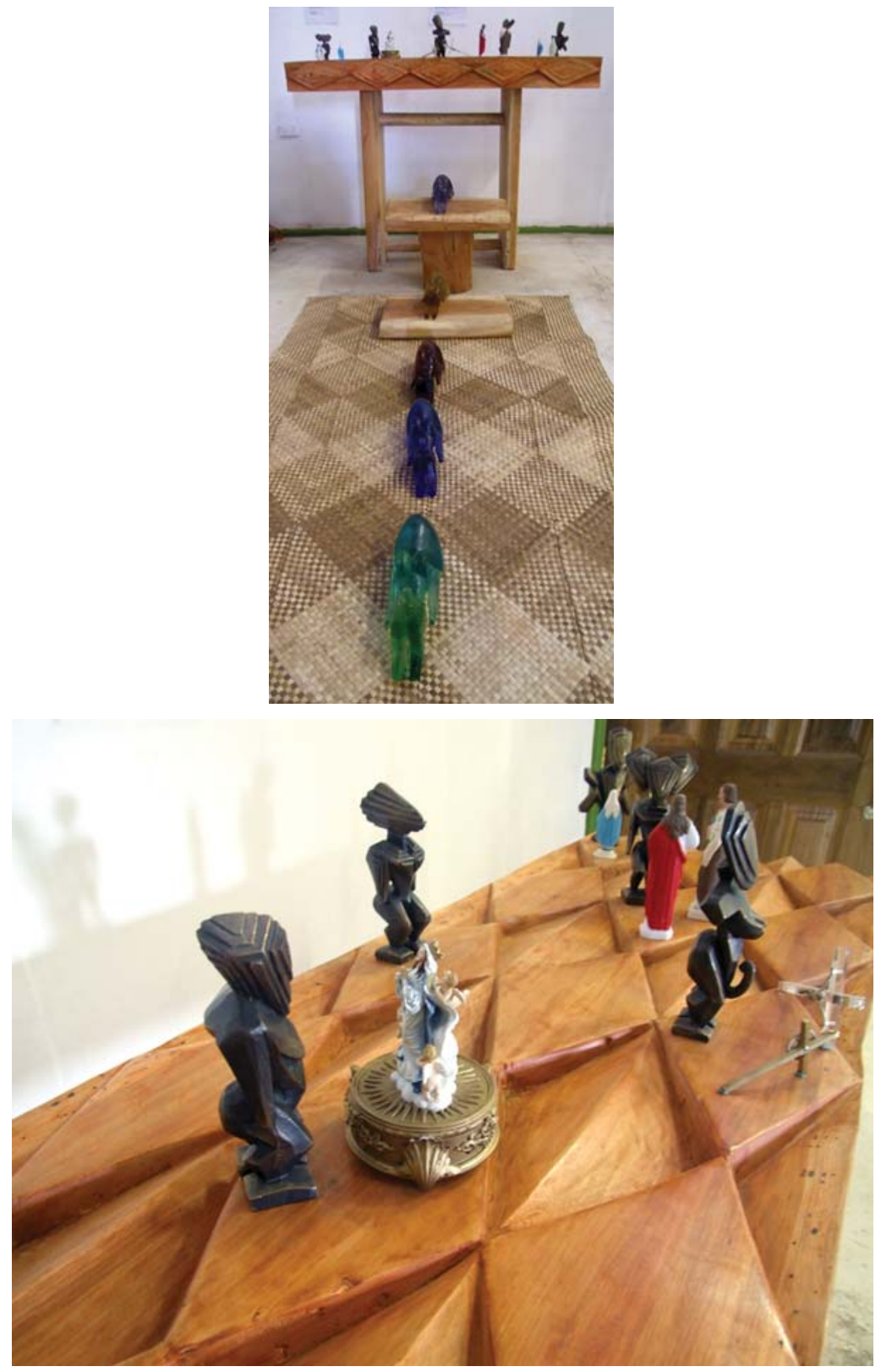

Melino, by Visesio Siasau, 2012.

Carved wood, cast bronze, cast glass, fabricated plastic figures, and woven pandanas mat. Bronze figures $25 \mathrm{~cm} \times 8 \mathrm{~cm}$; glass figures $40 \mathrm{~cm} \times \mathrm{I}_{5} \mathrm{~cm}$. Exhibited at the I I th Festival of Pacific Arts, Honiara, Solomon Islands, July 2012.

The halatapu (sacred path) leading to the altar is lined with sacrificial Tongan deities to signify the uho (intrinsic qualities) and fuo (external qualities), while the figures on the altar represent discourse among deities. Photos by Katherine Higgins. 
